J. Dairy Sci. 99:5325-5334

http://dx.doi.org/10.3168/jds.2016-10952

(C) American Dairy Science Association ${ }^{\circledR}, 2016$.

\title{
Characteristics of lactic acid bacteria isolates and their effect on silage fermentation of fruit residues
}

\author{
Jinsong Yang, ${ }^{*}$ Haisheng Tan, $\dagger$ and Yimin Cai $\ddagger^{1}$ \\ ${ }^{*}$ College of Food Science and Technology, Hainan University, Haikou, Hainan 570228, China \\ †College of Materials and Chemical Engineering, Hainan University, Haikou, Hainan 570228, China \\ $\ddagger$ National Institute of Livestock and Grassland Science, Tsukuba, Ibaraki 305-0901, Japan
}

\section{ABSTRACT}

The natural lactic acid bacteria (LAB) population, chemical composition, and silage fermentation of fruit residues were studied. Eighty-two strains of LAB were isolated from fruit residues such as banana leaf and stem, pineapple peel, and papaya peel. All strains were gram-positive and catalase-negative bacteria, and they were divided into 7 groups $(A-G)$ according to morphological and biochemical characters. Strains in groups A to F were rods, and group $\mathrm{G}$ was cocci. Group $\mathrm{F}$ produced gas from glucose; other groups did not. Groups $\mathrm{A}$ to $\mathrm{C}$ and $\mathrm{F}$ formed DL-lactic acid, whereas groups D, E, and G formed L-lactic acid. Based on the $16 \mathrm{~S}$ rRNA gene sequence and DNA-DNA hybridization analysis, groups A to G strains were identified as Lactobacillus plantarum (54.9\% of the total isolates), Lactobacillus paraplantarum (3.6\%), Lactobacillus nagelii (8.5\%), Lactobacillus perolens (4.9\%), Lactobacillus casei $(11.0 \%)$, Lactobacillus fermentum (9.8\%), and Enterococcus gallinarum (7.3\%), respectively. Lactobacillus plantarum and Lactobacillus casei are the most frequently isolated from fruit residues as a dominant species, and they could grow at a lower $\mathrm{pH}$ conditions and produce more lactic acid than other isolates. Pineapple and papaya peels contained higher crude protein (11.5-13.8\%) and water-soluble carbohydrate (16.8-22.4\%), but lower acid detergent fiber contents (21.2 to $26.4 \%$ ) than banana stems and leaves $(8.2 \%$ crude protein, $42.8 \%$ acid detergent fiber, and $5.1 \%$ water-soluble carbohydrate). Compared with banana stem and leaf silages, the pineapple and papaya peel silages were well preserved with a lower $\mathrm{pH}$ and higher lactate content. The study suggests that the fruit residues contain excellent LAB species and abundant feed nutrients, and that they can be preserved as silage to be potential food resources for livestock.

Received January 27, 2016.

Accepted March 9, 2016.

${ }^{1}$ Corresponding author: cai@affrc.go.jp
Key words: fruit residue, lactic acid bacteria, silage fermentation

\section{INTRODUCTION}

Banana, pineapple, and papaya are popular tropical fruits in the world; their production per year worldwide was 81.2 million, 18.8 million, and 0.3 million tonnes, respectively (Liu and Zhang, 2013). Hainan Island, located in the South China Sea, has a humid subtropical climate with warmer temperatures and tropical monsoon climate (Tang et al., 2008). Commercial processing of tropical fruits produces large quantities of residues every year in many countries, including China, but some residues are burned and dumped into landfills whereas others are used as compost, which leads to wasted resources and possible environmental problems because of unsuitable disposal (Ouyang, 2010). Demand for efficient use of food byproducts has increased due to economic and environmental concerns. Fruit residues from bananas, pineapples, and papayas are high in nutrients such as vitamins, minerals, and fiber (Council for Science and Technology, 2005) and can be potential feed resources for livestock. However, these fruit residues are highly perishable because of their high moisture content. Technology to provide long-term storage for the resulting silage as high quality animal feed needs to be developed.

Silage is now a common preserved fresh forage as feed in the world, and this fermentation technology is also considered to be available for the preservation and preparation of fruit residue. Generally, silage preservation depends on the production of sufficient acid to inhibit activity of undesirable microorganisms under anaerobic conditions (Cai et al., 1998). Naturally occurring lactic acid bacteria (LAB) are responsible for silage fermentation and can also influence silage quality (Lin et al., 1992). During silage fermentation, LAB convert sugar into lactic acid (Muck, 1989). As a result, the $\mathrm{pH}$ is reduced and the forage is preserved (Cai, 1999). However, from a silage fermentation point of view, to 
our knowledge, very little information is available on the silage preparation with fruit residues.

In the present experiment, 82 strains of LAB were isolated from fruit residues of banana, pineapple, and papaya. Their taxonomic status was studied through 16S rDNA sequence and DNA-DNA hybridization analysis. To develop the silage fermentation technique for tropical fruits residues, their natural LAB population, chemical composition, and silage fermentation were also studied.

\section{MATERIALS AND METHODS}

\section{Fruit Residue Collection and Microbiological Analysis}

Samples of banana (Musa sapientum L.) stems and leaves were collected from the Research Base of Tropical Crops Genetic Resources Institute of Tropical Agricultural Sciences Academy of China (Danzhou, Hainan province, China). As shown in Table 1, fruit residue samples of pineapple [Ananas comosus (L.) Merr.] peels and papaya [Chaenomeles speciosa (Sweet) Nakai] peels were collected from a local fruit processing factory (Kangle Foods factory, Danzhou, Hainan province, China).

The number of microorganisms in the fruit residue was measured by the plate count method. Fruit residue samples $(10 \mathrm{~g})$ were blended with $90 \mathrm{~mL}$ of sterilized water, and were serially diluted $10^{-1}$ to $10^{-5}$ in sterilized water. The number of LAB was measured by the plate count method on lactobacilli de Man, Rogosa, Sharpe (MRS) agar (Difco Laboratories, Detroit, MI) incubated at $30^{\circ} \mathrm{C}$ for $48 \mathrm{~h}$ under anaerobic conditions (Anaerobic box; TE-HER Hard Anaerobox, ANX-1; Hirosawa Ltd., Tokyo, Japan). For isolation of LAB, 10 to 20 strains on MRS agar medium were picked randomly from each silage sample, and a total of 86 isolates were collected, of which 82 isolates were considered to be LAB, as determined by the Gram stain appearance, catalase test, and lactic acid productivity, and their physiological properties were then determined by the isolation and identification methods for LAB (Kozaki et al., 1992). Coliform bacteria were counted on blue light agar (Nissui-seiyaku, Tokyo, Japan) incubated at $30^{\circ} \mathrm{C}$ for $48 \mathrm{~h}$; mold and yeast were counted on potato dextrose agar (Nissui-seiyaku) incubated for $24 \mathrm{~h}$ at $30^{\circ} \mathrm{C}$. Yeast was distinguished from mold and bacteria by colony appearance and observation of cell morphology. Bacilli and aerobic bacteria were distinguished by the colony shape and counted on nutrient agar (Nissui-seiyaku) incubated for $24 \mathrm{~h}$ at $30^{\circ} \mathrm{C}$ under aerobic conditions. Colonies were counted as viable numbers of microorganisms in colony forming units per gram of fresh matter (FM). Each LAB colony was purified twice by streaking on a MRS agar plate. The pure cultures were grown on MRS agar at $30^{\circ} \mathrm{C}$ for 24 $\mathrm{h}$, resuspended in a solution of nutrient broth (Difco) and dimethyl sulfoxide at a ratio of 9:1, and stored as stock cultures in a deep freezer (Sanyo, Tokyo, Japan) at $-80^{\circ} \mathrm{C}$ until further examination.

\section{Morphological, Physiological, and Biochemical Test}

Gram stain of LAB and morphological characteristics were determined after $24 \mathrm{~h}$ of incubation on MRS agar. Catalase activity and gas production from glucose were determined as described by Kozaki et al. (1992). Growth at different temperatures was detected in MRS broth after incubation at 5 and $10^{\circ} \mathrm{C}$ for $10 \mathrm{~d}$, and at 45 and $50^{\circ} \mathrm{C}$ for $7 \mathrm{~d}$. Growth at $\mathrm{pH} 2.5,3.0,3.5,4.0$, and 7.0 was observed in MRS broth after incubation at $30^{\circ} \mathrm{C}$ for $7 \mathrm{~d}$. Salt tolerance of LAB was tested in MRS broth containing 3.0 and $6.5 \% \mathrm{NaCl}$. Carbohydrate assimilation and fermentation of 49 different compounds with one control were identified on API $50 \mathrm{CH}$ strips (bioMerieux, Tokyo, Japan). These strains were divided into 7 groups $(\mathrm{A}-\mathrm{G})$ according to morphological and biochemical characters, and the representative strains of each group were selected by their different fermentation patterns of API $50 \mathrm{CH}$.

Table 1. Lactic acid bacteria strains used in this study ${ }^{1}$

\begin{tabular}{lll}
\hline Sample & Collection site & Representative strain \\
\hline Banana stem and leaf & $\begin{array}{l}\text { The Research Base of Tropical Crops Genetic Resources Institute of } \\
\text { Tropical Agricultural Sciences Academy of China, Danzhou, Hainan } \\
\text { province, China }\end{array}$ & HN12, HN15, HN16, HN17, HN18 \\
Pineapple peel & $\begin{array}{l}\text { Fruit processing factory, Kangle Foods factory, Danzhou, Hainan } \\
\text { province, China }\end{array}$ & HN2, HN6 \\
Papaya peel & $\begin{array}{l}\text { Fruit processing factory, Kangle Foods factory, Danzhou, Hainan } \\
\text { province, China }\end{array}$ & HN1, HN5, HN13, HN14 \\
\hline
\end{tabular}

${ }^{1} \mathrm{HN}$ strains were determined by the Gram stain appearance, catalase test, and lactic acid productivity. The representative strains were selected by their different morphological and biochemical characters. 


\section{S rRNA Gene Sequence and DNA-DNA Hybridization Analysis}

Cells of representative strains grown for $8 \mathrm{~h}$ in MRS broth at $30^{\circ} \mathrm{C}$ were used for DNA extraction and purification (Saito and Miura, 1963; Tamaoka and Komagata, 1984). The $16 \mathrm{~S}$ rDNA sequence coding region was amplified by PCR and performed in a PCR ThermalCycler (GenAmp PCR System 9700; PE Applied Biosystems, Foster City, CA) and reagents from a Takara Taq PCR Kit (Takara Shuzo Co., Ltd., Otsu, Japan; Suzuki et al., 1996; Cai et al., 1998). Sequencing was performed twice on both strands by the dideoxy method using a PRISM BigDye Terminator Cycle Sequence Ready Reaction Kit (Applied Biosystems) in combination with an Applied Biosystems model 310A automated sequencing system. Searching $16 \mathrm{~S}$ rDNA gene sequence similarity was performed at GenBank data library by using the BLAST program. Then the sequence information was introduced into the CLUSTAL W software program (Hitachi Software Engineering Co.) for assembly and alignment (Thompson et al., 1994). The 16S rDNA gene sequences of isolates were compared with sequences from the strains of LAB held in the GenBank. Nucleotide substitution rates were calculated (Kimura and Ohta, 1972), and phylogenetic trees were constructed by the neighbor-joining method (Saito and Nei, 1987). Bacillus subtilis NCDO 1769 was used as an outgroup organism. The topology of trees was evaluated by bootstrap analysis of the sequence data with CLUSTAL W software based on 100 random resamplings (Thompson et al., 1994).

For DNA-DNA hybridization test, the DNA of isolates was extracted from cells harvested from MRS broth culture which had been incubated for $8 \mathrm{~h}$ at $30^{\circ} \mathrm{C}$. It was purified by the procedure of Saito and Miura (1963). The DNA base composition was determined by the method of Tamaoka and Komagata (1984) by using high-performance liquid chromatography following enzymic digestion of DNA to deoxyribonucleosides. The DNA-DNA relatedness was determined by the method of Ezaki et al. (1989) by using photobiotin and microplates.

\section{Laboratory Silage Preparation}

Silages were prepared using a small-scale silage fermentation system (Cai, 1999). Approximately 1,000-g portions of fruit residue, chopped into about $20-\mathrm{mm}$ lengths, were packed into plastic film bags (Huanan type, $26 \times 38 \mathrm{~cm}$; Deli, Guangzhou, China) and sealed with a vacuum sealer (XS-628; Anxi County, Fujian Province Machinery Plant, China). The film bag silos were stored outdoors at 22.2 to $31.6^{\circ} \mathrm{C}$ for $60 \mathrm{~d}$ of fermentation. Three silos per treatment were used for chemical analysis.

\section{Chemical and Statistical Analysis}

The chemical composition of the fruit residue samples and silages was determined by conventional methods (Association of Official Analytical Chemists, 1990). The DM content of the fresh fruit residue was determined by oven-drying at $65^{\circ} \mathrm{C}$ for $48 \mathrm{~h}$. Fermentation products of the fruit residue silages were determined from coldwater extracts. Wet silage (10 g) was homogenized with $90 \mathrm{~mL}$ of sterilized distilled water. The $\mathrm{pH}$ was measured with a glass electrode $\mathrm{pH}$ meter (MP230, Mettler Toledo, Greifensee, Switzerland), and ammonia-N was determined by steam distillation of the filtrates. The organic acid and water-soluble carbohydrate (WSC) contents were measured by HPLC (Cai et al., 1998).

The data were analyzed by ANOVA and means were then compared for significance by Duncan's multiple range method. All statistical procedures were performed using the statistical packages for the social sciences (SPSS 13.0 for Windows; SPSS Inc., Chicago, IL).

\section{RESULTS}

The counts of viable microorganisms in fruit residues are shown in Table 2. Overall $10^{3}$ to $10^{5}$ ( $\mathrm{cfu} / \mathrm{g}$ of FM) LAB, $10^{3}$ to $10^{4}$ coliform bacteria, $10^{5}$ to $10^{6}$ aerobic bacteria, $10^{2}$ to $10^{4}$ bacilli, and $10^{3}$ to $10^{5}$ yeast were found in the 3 types of fruit residue samples. The mold was less than $10^{2}$ in all the fruit residue samples. Lactobacillus plantarum and L. casei are the most frequently isolated from fruit residues than other isolates.

Morphological, physiological, biochemical properties, $16 \mathrm{~S}$ rRNA gene sequence similarity and DNA-DNA hybridization analysis of representative LAB strains isolated from fruit residues are shown in Tables 3 and 4. All isolates were gram-positive and catalase-negative bacteria. These isolates were unable to grow at $50^{\circ} \mathrm{C}$, and were able to grow at $\mathrm{pH} 4.0$ to 7.0 , at $3.0 \% \mathrm{NaCl}$, and at 10 and $45^{\circ} \mathrm{C}$. Strains in group A, B, and E grew at low $\mathrm{pH}$ condition and produced more lactic acid in MRS broth, compared with group C, D, F, and G.

According to the morphological, physiological, and biochemical properties, those strains were divided into 7 groups (A to G). Strains in group A (representative strains: HN1, HN2, HN3, HN4, HN5, HN6, HN8, HN 9 , and HN11) and group B (HN 12) were similar to group C (HN15 and HN16); they were rods that formed DL-lactic acid. Group A produced acid from ribose and Q-methyl-D-mannoside, which made it different from group C. Groups D and E were same with homofermentative rods that formed L-lactic acid. However, 


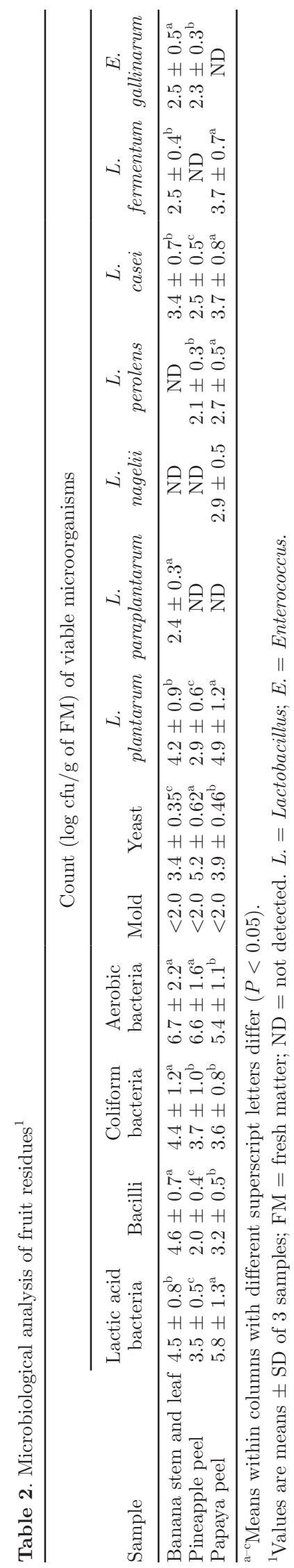

group E (HN13 and HN14) did not produce acid from $\beta$-gentiobiose, differentiating it from group $\mathrm{E}$ and other groups. Group F (HN7) consisted of rods that produced gas from glucose, and group G (HN10 and HN17) consisted of cocci that formed the L-isomer of lactic acid, which made it different from other groups.

The phylogenetic trees of the $16 \mathrm{~S}$ rRNA gene sequence are shown in Figures 1 and 2, respectively. Following phylogenetic analysis, strains in group A and B were clearly assigned to the genus Lactobacillus because it grouped on the phylogenetic tree together with $L$. pentosus and $L$. plantarum, including 2 subspecies, $L$. paraplantarum and L. arizonensis, in a $100 \%$ bootstrap cluster. Furthermore, strains in group A appeared to be equally linked to L. plantarum ssp. plantarum, L. plantarum ssp. argentoratensis, and L. pentosus, whereas the group B was phylogenetically associated with L. paraplantarum. Strains in group A and group B both showed their similarity of $16 \mathrm{~S}$ rDNA sequence more than $99.3 \%$ to L. plantarum ssp. plantarum and L. paraplantarum. The DNA-DNA relatedness between group A and L. plantarum was 82.4 to $99.5 \%$, and between group B and L. paraplantarum was $93.0 \%$. Strains in groups C, D, and F were closely related to $L$. nagelii, L. perolens, and L. fermentum with each having a bootstrap of $100 \%$, respectively. The DNA-DNA relatedness between their group and their type stains was more than $84.8 \%$. Strains in group $\mathrm{E}$ were both closely related $L$. casei in $91 \%$ of bootstrap analyses. The DNA-DNA relatedness between group E and type strain L. casei was 84.2 to $93.7 \%$. Strains in group G were placed in the Enterococcus cluster because they grouped on the phylogenetic tree with the Enterococcus casseliflavus group. Group G strains showed Enterococcus gallinarum or E. casseliflavus being the most closely related species, and they exhibited 90.1 to $93.6 \%$ DNADNA relatedness to type strain E. gallinarum.

The LAB species diversity was observed because 7 species were also identified: L. plantarum $(54.9 \%$ of the total isolates), L. paraplantarum $(3.6 \%)$, L. nagelii (8.5\%), L. perolens $(4.9 \%)$, L. casei $(11.0 \%)$, L. fermentum $(9.8 \%)$, and E. gallinarum (7.3\%). Furthermore, homofermentative species accounted for $81.2 \%$ of the total LAB microflora.

Chemical composition and silage fermentation of fruit residues are shown in Table 5. The OM content of 3 fruit residues was similar, ranging from 85.8 to $88.2 \%$, and their moisture content was high, ranging from 85.5 to $94.3 \%$ on a FM basis. Pineapple and papaya peels had higher $(P<0.05) \mathrm{CP}$ contents $(11.5-13.8 \%)$ and lower $(P<0.05) \mathrm{ADF}$ contents $(21.2$ to $26.4 \%)$ than banana stems and leaves (8.2\% CP and $42.8 \% \mathrm{ADF})$. Total WSC for pineapple peels $(22.4 \%)$ and papaya 


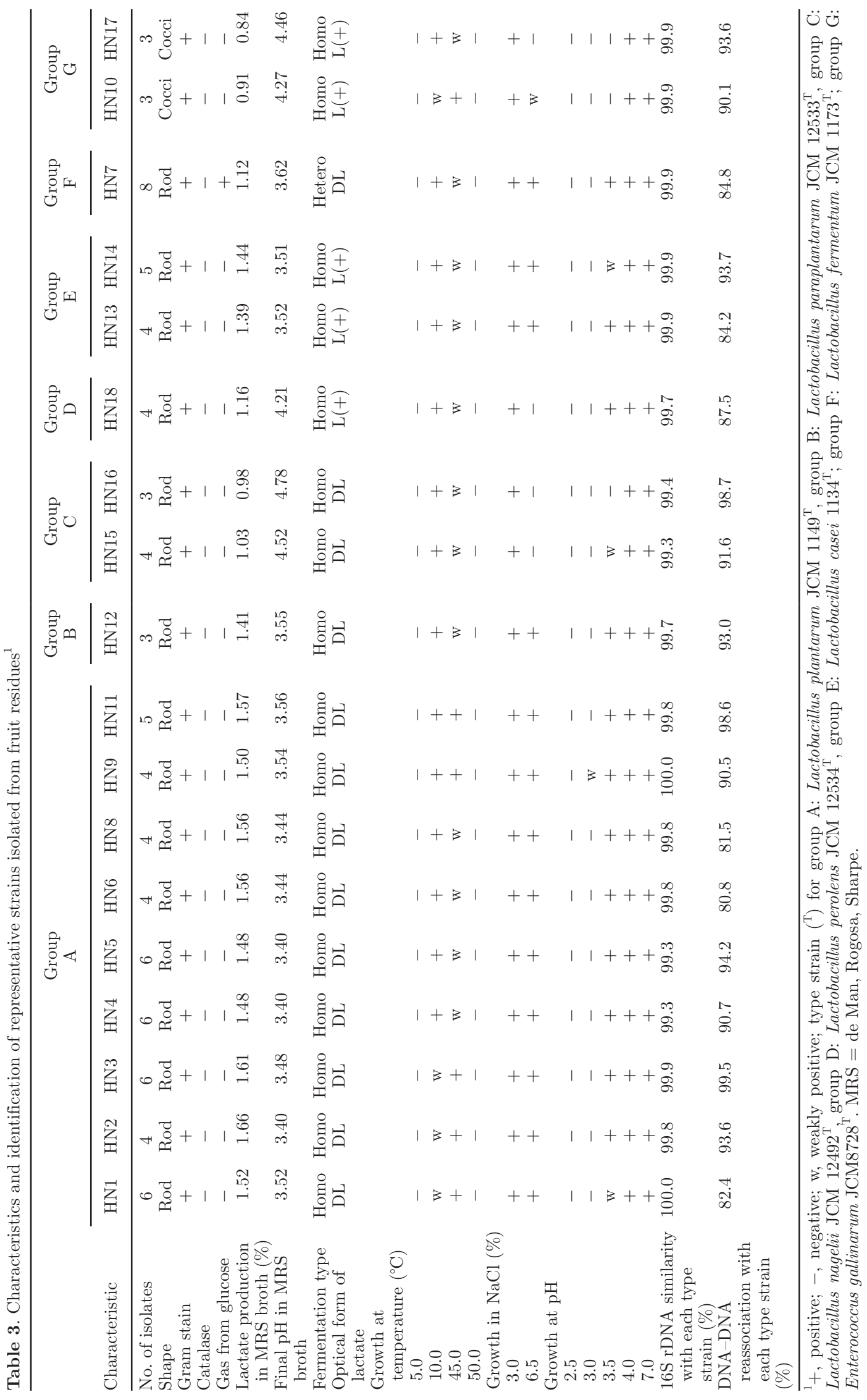




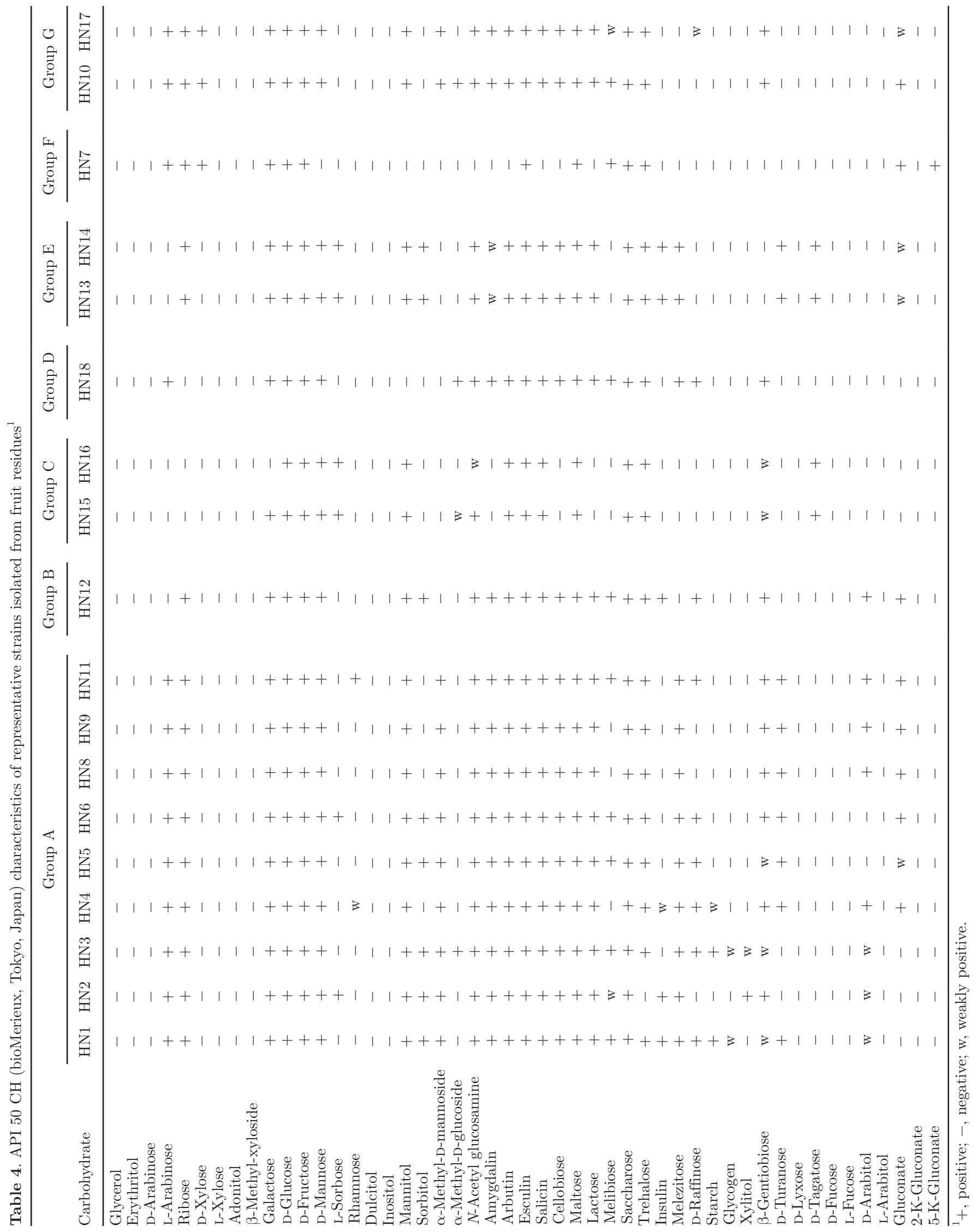




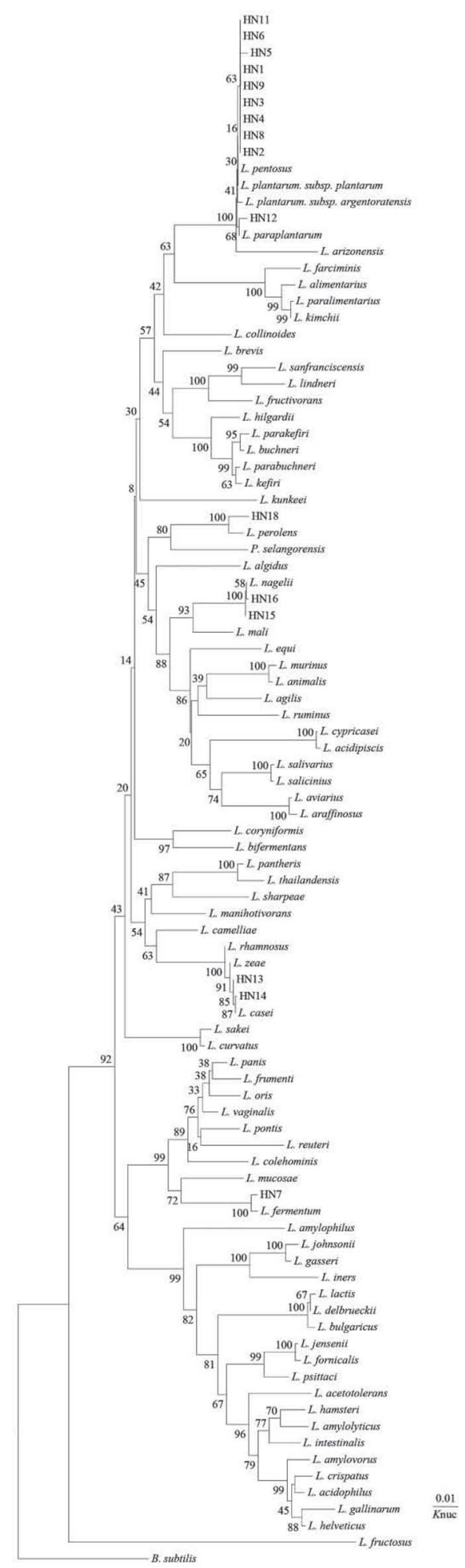

Figure 1. Phylogenetic tree showing the relative positions of Lactobacillus species and representative strains isolated from fruit residues as inferred by the neighbor-joining method of complete $16 \mathrm{~S}$ rDNA sequences. Bootstrap values for a total of 100 replicates are shown at the nodes of the tree. Bacillus subtilis is used as an outgroup. The bar indicates 1\% sequence divergence. L., Lactobacillus. Knuc, nucleotide substitution rates. peels $(16.8 \%)$ were higher $(P<0.05)$ than that of banana stems and leaves $(5.1 \%)$.

Overall, the pineapple and papaya peel silages were well preserved with a pH below $4.3(P<0.05)$ and higher lactic acid content over $18.9 \%(P<0.05)$ on a DM basis than those in banana stem and leaf silages. Compared with acetic acid content, the lactic acid contents in pineapple and papaya peel silages were

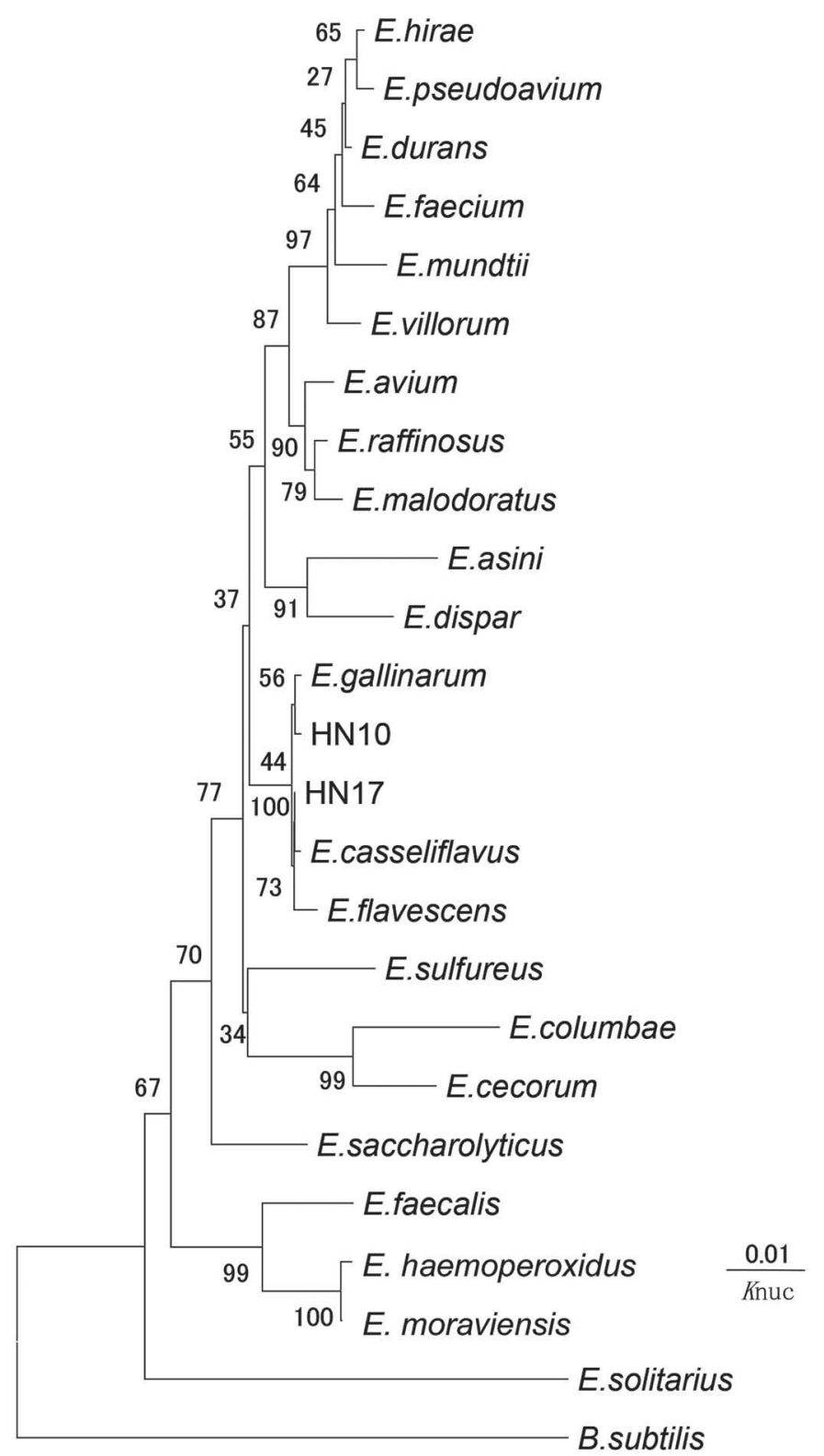

Figure 2. Phylogenetic tree showing the relative positions of Enterococcus species and representative strains isolated from fruit residues as inferred by the neighbor-joining method of complete $16 \mathrm{~S}$ rDNA sequences. Bootstrap values for a total of 100 replicates are shown at the nodes of the tree. Bacillus subtilis is used as an outgroup. The bar indicates 1\% sequence divergence. E., Enterococcus. Knuc, nucleotide substitution rates. 
Table 5. Chemical composition and silage quality of fruit residues ${ }^{1}$

\begin{tabular}{lccc}
\hline Item & $\begin{array}{c}\text { Banana stems } \\
\text { and leaves }\end{array}$ & $\begin{array}{c}\text { Pineapple } \\
\text { peel }\end{array}$ & $\begin{array}{c}\text { Papaya } \\
\text { peel }\end{array}$ \\
\hline Chemical composition & & & \\
Moisture content (\%) & $85.5 \pm 1.1^{\mathrm{b}}$ & $94.3 \pm 2.2^{\mathrm{a}}$ & $93.0 \pm 1.6^{\mathrm{a}}$ \\
OM (\% of DM) & $85.8 \pm 1.7^{\mathrm{c}}$ & $87.3 \pm 0.7^{\mathrm{b}}$ & $88.2 \pm 1.5^{\mathrm{a}}$ \\
CP (\% of DM) & $8.2 \pm 0.5^{\mathrm{c}}$ & $13.8 \pm 0.9^{\mathrm{a}}$ & $11.5 \pm 0.7^{\mathrm{b}}$ \\
Ether extracts (\% of DM) & $2.3 \pm 0.1^{\mathrm{a}}$ & $2.1 \pm 0.3^{\mathrm{a}}$ & $1.5 \pm 0.2^{\mathrm{b}}$ \\
NDF (\% of DM) & $44.3 \pm 1.1^{\mathrm{a}}$ & $28.5 \pm 0.6^{\mathrm{b}}$ & $22.2 \pm 0.5^{\mathrm{c}}$ \\
ADF (\% of DM) & $42.8 \pm 1.1^{\mathrm{a}}$ & $26.4 \pm 0.7^{\mathrm{b}}$ & $21.2 \pm 0.6^{\mathrm{c}}$ \\
WSC (\% of DM) & $5.1 \pm 0.2^{\mathrm{c}}$ & $22.4 \pm 0.8^{\mathrm{a}}$ & $16.8 \pm 0.7^{\mathrm{b}}$ \\
Silage quality & & & \\
Moisture content (\%) & $46.7 \pm 0.8^{\mathrm{c}}$ & $94.5 \pm 1.1^{\mathrm{a}}$ & $93.3 \pm 1.6^{\mathrm{b}}$ \\
pH & $2.3 \pm 0.1^{\mathrm{a}}$ & $3.4 \pm 0.3^{\mathrm{b}}$ & $3.4 \pm 0.2^{\mathrm{b}}$ \\
Lactic acid (\% of DM) & $6.9 \pm 0.2^{\mathrm{b}}$ & $18.9 \pm 1.2^{\mathrm{b}}$ & $21.6 \pm 0.5^{\mathrm{a}}$ \\
Acetic acid (\% of DM) & $\mathrm{ND}$ & $7.2 \pm 0.5^{\mathrm{a}}$ & $6.8 \pm 0.3^{\mathrm{b}}$ \\
Butyric acid (\% of DM) & $\mathrm{ND}$ & $\mathrm{ND}$ & $\mathrm{ND}$ \\
Propionic acid (\% of DM) & $4.1 \pm 0.4^{\mathrm{a}}$ & $3.3 \pm 0.2^{\mathrm{b}}$ & $\mathrm{ND}$ \\
Ammonia-N (g/kg of FM) & & $3.2 \pm 0.2^{\mathrm{b}}$ \\
\hline
\end{tabular}

${ }^{\mathrm{a}-\mathrm{c}}$ Means in the same row with different superscripts differ $(P<0.05)$.

${ }^{1}$ Silage was stored for $60 \mathrm{~d}$, values are means \pm SD of 3 silage samples. WSC, water-soluble carbohydrate; FM, fresh matter; ND, not detected.

higher, whereas those in banana stem and leaf silages were lower. The butyric acid and propionic acid could not be detected from the all silages, showing that their fermentation was of good quality. The pineapple and papaya peel silages showed ammonia-N content at 3.2 to $3.3 \mathrm{~g} / \mathrm{kg}$ of FM, which was lower $(P<0.05)$ than that in banana stem and leaf silages $(4.1 \mathrm{~g} / \mathrm{kg}$ of FM).

\section{DISCUSSION}

Generally, the epiphytic LAB numbers have become a significant factor in predicting the adequacy of silage fermentation and determining whether or not to apply bacterial inoculants to silage materials (McDonald et al., 1991; Lin et al., 1992). Cai (1999) reported that $\mathrm{LAB}$ are usually present in forages or vegetables in very low numbers (less than $10^{3}$ ). When LAB fail to produce sufficient lactic acid during fermentation to reduce the $\mathrm{pH}$ and inhibit the growth of clostridia, the resulting silage will be of poor quality. As shown in Table 2, relatively high numbers of $10^{3}$ to $10^{5}$ (cfu/g of FM) LAB were present in these residues of banana, pineapple, and papaya. Natural strains of Lactobacillus plantarum and L. case $i$ are the dominant microbial populations on these fruit residues, and both strains could play an important role as the strong producer of lactic acid during silage fermentation; thus, inoculation of additional microbes to control fermentation might not be necessary.

In the present study, the isolates were gram-positive and catalase-negative rods or cocci that produced lactic acid from glucose. These properties show that those strains belong to the LAB species. Strains in groups A to $\mathrm{G}$ were different in cell form, fermentative type, and isomers of lactic acid, but they could not be identified to the species level on the basis of phenotypic characteristics.

The identification and genetic interrelationships of the LAB have been studied extensively in $16 \mathrm{~S}$ rRNA sequence and DNA-DNA hybridization experiments, and new species isolated from silage have been added (Cai et al., 1998; Cai, 1999). Recent results have clearly indicated that the LAB genera Lactobacillus, Pediococcus, Enterococcus, Leuconostoc, Weissella, and Lactococcus exhibited a high degree of sequence similarity to each other and form a phylogenetically coherent group that distinguishes them from other bacteria (Collins et al., 1989, 1990, 1993). In the present study, the representative strains of groups A to $\mathrm{F}$ were placed in the genus Lactobacillus and group G placed in the genus Enterococcus in the phylogenetic tree, confirming that these strains belong to the genus Lactobacillus and Enterococcus.

Strains in group A and B were phylogenetically close to the L. plantarum group, including L. pentosus and L. paraplantarum, and their similarities of $16 \mathrm{~S} \mathrm{rDNA}$ sequence were more than 99\%. Ennahar et al. (2003) reported that the 2 species of $L$. plantarum and $L$. pentosus have very similar $16 \mathrm{~S}$ rDNA sequences that differ by only $2 \mathrm{bp}$; they can only be distinguished using phylogenetic analysis of sequences of the $16 \mathrm{~S}-23 \mathrm{~S}$ large space region or partial sequences of the rec $A$ gene. As shown in Table 3 , groups $\mathrm{A}$ and $\mathrm{B}$ showed a higher DNA-DNA relatedness $(>80.8 \%)$ with their each type strains, suggesting that group A and B strains belonged to L. plantarum and L. paraplantarum. Groups E and 
$\mathrm{G}$ have the same problem as the similar $16 \mathrm{~S}$ rDNA sequences. Group E species were most closely related to the $L$. casei group including $L$. zeae and L. rhamnosus. It is widely acknowledged that the $L$. casei group belongs to the same $16 \mathrm{~S}$ rDNA phylogenetic group and the species level can be distinguished by the DNA-DNA homology method (Torriani et al., 2001). In the present study, the DNA-DNA relatedness of group E with the type strain was more than $84.2 \%$. Therefore, the result demonstrated that strains in group E could be assigned to $L$. casei. On the other hand, in group G, strain HN10 and E. gallinarum, and strain HN17 and E. casseliflavus were the most closely related pair on the phylogenetic tree, whereas they were both identified as E. gallinarum based on the DNA-DNA hybridization analysis result.

Strains in groups C, D, and F with their type strains were more than $99.3 \%$, and with other type strains they were less than $98.0 \%$ based on the $16 \mathrm{~S}$ rRNA gene sequence analysis. The results demonstrated that these strains could be assigned to L. nagelii, L. perolens, and L. fermentum. In fact, the DNA-DNA hybridization data also supported these results; these strains had DNA homology values more than $87.5 \%$ with each type strain, respectively.

Following biochemical and phylogenetic analysis, isolates from fruit residues fell within well-recognized groups of LAB and their characteristics belonged to the genera Lactobacillus and Enterococcus. Five species were observed and identified, and $L$. plantarum and $L$. case $i$ were the dominant species among these isolates from the 3 kinds of fruit residues. Furthermore, to our knowledge, this is the first report of natural L. nagelii and $L$. perolens on fruit.

Cai et al. (1998) and Cai (1999) reported that some cocci create an aerobic environment suitable for the development of lactobacilli only in the early stage during silage fermentation processes. In contrast with the lactic acid-producing cocci, the Lactobacilli (rod) are important promoters of lactic acid fermentation for a longer time. Many studies have reported that the inoculation of forage with homofermentative lactobacilli such as L. casei or L. plantarum have beneficial effects on promoting lactic acid fermentation and improving silage quality. In the present study, the pineapple and papaya peel silages were well preserved, with high lactic acid contents and low $\mathrm{pH}$ values. However, the lactic acid contents in these silages were higher, whereas in banana stem and leaf silages were lower than acetic acid. The factors involved in assessing fermentation quality include the chemical composition of the fruit residue material and the physiological properties of epiphytic bacteria. As shown in Table 5, the pineapple and papaya peel residues have relatively high WSC content with 15 to $20 \%$ on DM basis and high num- ber of epiphytic LAB $\left(10^{4} \mathrm{cfu} / \mathrm{g}\right.$ of $\left.\mathrm{FM}\right)$. In addition, L. plantarum and L. casei are the dominant species distributed on these fruit residues. During the silage fermentation, these natural LAB could use the sugars to produce sufficient lactic acid to reduce $\mathrm{pH}$, and the resulting silage was of good quality. On the other hand, the acetic acid content of banana stem and leaf silages was higher than lactic acid. These results may be evidence that a relatively low WSC at $5.1 \%$ of DM was present in the material; furthermore, LAB were unable to use the WSC to produce sufficient lactic acid to inhibit the growth of acetic acid-producing bacteria and allowing acetic acid fermentation to occur.

Fruit byproducts from the food industry have increased rapidly in recent years in China (Yang et al., 2010; Wang et al., 2012), increasing the demand for efficient use of food byproducts due to economic and environmental concerns. It was demonstrated that the fruit residues contained effective LAB species in silage fermentation and abundant feed nutrients, and that silage prepared with local fruit residues is a very useful animal feed resource.

\section{CONCLUSIONS}

The natural strains L. plantarum and L. casei are the most frequently isolated from fruit residues as a dominant species; they could grow at low $\mathrm{pH}$ condition and promote lactic acid fermentation. Based on the analysis of silage fermentation and chemical composition, we have found that the fruit residue can be preserved as silage and has great potential as a feed source for livestock.

\section{ACKNOWLEDGMENTS}

This work was supported by the National Natural Science Foundation of China (no. 31460621) and the National Natural Science Foundation of Hainan Province, China (no. 314073).

\section{REFERENCES}

Association of Official Analytical Chemists. 1990. Official Methods of Analysis. 15th ed. Association of Official Analytical Chemists, Arlington, VA.

Cai, Y. 1999. Identification and characterization of Enterococcus species isolated from forage crops and their influence on silage fermentation. J. Dairy Sci. 82:2466-2471.

Cai, Y., Y. Benno, M. Ogawa, S. Ohmomo, S. Kumai, and T. Nakase. 1998. Influence of Lactobacillus spp. from an inoculant and of Weissella and Leuconostoc spp. from forage crops on silage fermentation. Appl. Environ. Microbiol. 64:2982-2987.

Collins, M. D., C. Ash, J. A. Farrow, S. Wallbank, and A. M. Williams. 1989. 16S ribosomal ribonucleic acid sequence analyses of lactobacilli and related taxa. Description of Vagococcus fluvialis gen. nov., sp. nov. J. Appl. Bacteriol. 67:453-460. 
Collins, M. D., J. Metaxopoulos, and S. Wallbanks. 1993. Taxonomic study on some leuconostoc-like organisms from fermented sausages: Description of a new genus Weissella for the Leuconostoc paramesenteroides group of species. J. Appl. Bacteriol. 75:595-603.

Collins, M. D., A. M. Williams, and S. Wallbanks. 1990. The phylogeny of Aerococcus and Pediococcus as determined by $16 \mathrm{~S}$ rRNA sequence analysis: Description of Tetragenococcus gen. nov. FEMS Microbiol. Lett. 58:255-262.

Council for Science and Technology. 2005. Standard Tables of Food Composition in Japan. 5th ed. Ministry of Education, Culture, Sports, Science and Technology, the Government of Japan. National Printing Bureau, Tokyo (in Japanese with English translation). Pages 65-72.

Ennahar, S., Y. Cai, and Y. Fujita. 2003. Phylogenetic diversity of lactic acid bacteria associated with paddy rice silage as determined by $16 \mathrm{~S}$ ribosomal DNA analysis. Appl. Environ. Microbiol. 69:444-451.

Ezaki, T., Y. Hashimoto, and E. Yabuuchi. 1989. Fluorometric deoxyribonucleic acid-deoxyribonucleic acid hybridization in microdilution wells as an alternative to membrane filter hybridization in which radioisotopes are used to determine genetic relatedness among bacterial strains. Int. J. Syst. Bacteriol. 39:224-229.

Kimura, M., and T. Ohta. 1972. On the stochastic model for estimation of mutation distance between homologous proteins. J. Mol. Evol. 2:87-90.

Kozaki, M., T. Uchimura, and S. Okada. 1992. Experimental Manual of Lactic Acid Bacteria. Asakurashoten, Tokyo, pp. 34-37.

Lin, C., K. K. Bolsen, B. E. Brent, and D. Y. C. Fung. 1992. Epiphytic lactic acid bacteria succession during the pre-ensiling and ensiling periods of alfalfa and maize. J. Appl. Bacteriol. 73:375-387.

Liu, Y., and H. Zhang. 2013. World banana industry development and trends. World Agric. 10:76-79.

McDonald, P., N. Henderson, and S. Heron. 1991. The Biochemistry of Silage. 2nd ed. Chalcombe Publ., Marlow, Berkshire, UK.

Muck, R. E. 1989. Initial bacterial numbers on lucerne prior to ensiling. Grass Forage Sci. 44:19-25.
Ouyang, L. 2010. Study on the banana industry development in Hainan. Management \& Technol. SME 4:12-15.

Saito, H., and K. Miura. 1963. Preparation of transforming deoxyribonucleic acid by phenol treatment. Biochim. Biophys. Acta 72:619-629.

Saito, N., and M. Nei. 1987. The neighbor-joining method: A new method for reconstructing phylogenetic trees. Mol. Biol. Evol. 4:406-425.

Suzuki, K., J. Sasaki, M. Uramoto, T. Nakase, and K. Komagata. 1996. Agromyces mediolanus sp. nov., nom. rev., comb. nov., a species for "Corynebacterium mediolanum" Mamoli 1939 and for some anilineassimilating bacteria which contain 2,4-diaminobutyric acid in the cell wall peptidoglycan. Int. J. Syst. Bacteriol. 46:88-93.

Tamaoka, J., and K. Komagata. 1984. Determination of DNA base composition by reversed-phase high-performance liquid chromatography. FEMS Microbiol. Lett. 124:11-16.

Tang, S., Z. Zhao, H. Bi, and G. Xie. 2008. Climatic characteristics of Hainan Island and its utilization. J. Hainan Normal Univ. 21:343346.

Thompson, J. D., D. G. Higgins, and T. J. Gibson. 1994. CLUSTAL $\mathrm{W}$ : Improving the sensitivity of progressive multiple sequence alignment through sequence weighting, position-specific gap penalties and weight matrix choice. Nucleic Acids Res. 22:4673-4680.

Torriani, S., G. E. Felis, and F. Dellaglio. 2001. Differentiation of Lactobacillus plantarum, L. pentosus, and L. paraplantarum by recA gene sequence analysis and multiplex PCR assay with recA genederived primers. Appl. Environ. Microbiol. 67:3450-3454.

Wang, Q., H. Zhou, H. Tan, and J. Yang. 2012. Effect of different additives on banana stems silage quality. Guangdong Agric. Sci. 22:104-106.

Yang, J., Y. Cao, Y. Cai, and F. Terada. 2010. Natural populations of lactic acid bacteria isolated from vegetable residues and silage fermentation. J. Dairy Sci. 93:3136-3145. 